\title{
LEARNING FROM HOME SELAMA PANDEMI COVID-19 (STUDI KASUS ORANG TUA DAN GURU)
}

\author{
Maria Agape Widya Prasetya ${ }^{1}$, Eranus Yoga Kundhani ${ }^{2}$ \\ ${ }^{1,2}$ Universitas Kristen Satya Wacana
}

\begin{abstract}
Since the COVID-19 pandemic in Indonesia, all economic and educational activities have been suspended and replaced with online methods. In the education sector, it is known as learning from home (LFH), which requires interaction between students and teachers through online media with intermediary parents for students from Kindergarten and Elementary School. This research will discuss the problems, difficulties, and impacts felt by parents, teachers of elementary school, and how they adjust their learning methods at home during the COVID-19 pandemic. This research uses qualitative analysis methods and is analyzed by descriptive analysis. The subject of this study were the parents of kindergarten and elementary school students who work in offices, elementary school teachers, as well as teaching elementary student assistants other than parents. The result showed that the impact of the LFH are problems and difficulties where the teachers had to spend more time teaching children and making learning videos for material delivery and cost for purchase quota or internet to facilicate learning from home.
\end{abstract}

Keyword: LFH, methods of delivery material, effectiveness, time management, COVID-19

\begin{abstract}
Abstrak: Sejak adanya pandemi COVID-19 di Indonesia, seluruh aktivitas baik perekonomian maupun pendidikan ditutup sementara dan diganti dengan metode daring atau online. Pada sektor pendidikan dikenal dengan istilah learning from home (LFH) yang mana mengharuskan interaksi antara murid dengan guru melalui media online dengan perantara orang tua untuk siswa kelas rendah seperti TK (Taman Kanak-kanak) dan SD (Sekolah Dasar). Pada penelitian ini akan dibahas mengenai permasalahan, kesulitan, dan dampak yang dirasakan oleh orang tua siswa TK dan SD serta guru SD selama LFH dan cara orang tua untuk menyesuaikan metode pembelajaran di rumah selama masa pandemi COVID-19 ini. Penelitian ini menggunakan metode analisis kualitatif dan dianalisis dengan analisis deskriptif. Subjek penelitian ini adalah satu orang tua siswa TK dan satu orang tua siswa SD kelas rendah yang bekerja kantor dan satu guru SD serta satu pendamping pengajar siswa SD selain orang tua. Hasil penelitian menunjukkan bahwa dampak dari adanya LFH nya ini ialah berkaitan dengan masalah dan kesulitan yang dihadapi yaitu pada waktu untuk mendampingi anak dan membuat video pembelajaran serta biaya tambahan untuk membeli kuota atau pemasangan wifi demi mendukung pembelajaran anak.
\end{abstract}

Kata Kunci: LFH, metode penyampaian materi, efektifitas, manajemen waktu, COVID19

'Universitas Kristen Satya Wacana, Email: 222018018回student.uksw.edu

${ }^{2}$ Universitas Kristen Satya Wacana, Email: eranus.kundhani国uksw.edu 


\section{PENDAHULUAN}

Saat ini seluruh dunia sedang dilanda suatu wabah penyakit yang sangat besar dan mematikan, yaitu corona virus disease 2019 atau yang dikenal dengan COVID-19. Virus ini adalah jenis virus yang mudah menular antarindividu. Indonesia adalah salah satu Negara yang terdampak COVID-19 sejak bulan Maret 2020 silam (C et al., 2020). Pemerintah mengambil strategi untuk memutus mata rantai penyebaran virus ini dengan menerapkan Pembatasan Sosial Berskala Besar (PSBB) serta physical distancing selama masa pandemi ini. Masa pandemi akibat adanya COVID-19 (Corona Virus Disease 2019) ini membuat kegiatan dan aktivitas yang biasa dilakukan di luar rumah mengharuskan berkegiatan di dalam rumah, atau lebih dikenal dengan tagar \#dirumahaja. Aktivitas perkantoran berjalan seperti biasa, namun memakai metode work from home (WFH) dan aktivitas belajar mengajar juga berjalan seperti biasa dan memakai metode learning from home (LFH). Pembelajaran daring pun dipilih sebagai cara yang tepat untuk mengantisipasi tersebarnya virus COVID-19 lebih mendalam, karena dengan dilaksanakannya pembalajaran daring akan meminimalisir pertemuan tatap muka dan kerumunan (Syarifudin, 2020). Akan tetapi, dilaksanakannya pembelajaran daring pada bidang pendidikan tidak serta merta berjalan baik-baik saja, tentunya ada banyak pro dan kontra berkaitan dengan pembelajaran daring yang mana manfaat yang diperoleh lebih kecil daripada yang diharapkan (Wahyono et al., 2020).

Di masa pandemi seperti sekarang ini, teknologi adalah kunci utama kelancaran dan kesuksesan kegiatan yang individu lakukan. Masa adaptasi sangat diperlukan dan sangat penting bagi para pekerja, pelajar/ mahasiswa, tak terkecuali bagi ibu rumah tangga. Bagi orang tua yang memiliki anak-anak kecil atau usia TK maupun SD kelas rendah (6-9 tahun),
LFH juga dapat berdampak kepada mereka karena peran orang tua disini adalah sebagai guru sementara dan perantara selama masa pandemi berlangsung.

Menteri Pendidikan dan Kebudayaan Republik Indonesia mengeluarkan Surat Edaran Nomor 4 Tahun 2020 Tentang Pelaksanaan Kebijakan Pendidikan Dalam Masa Darurat Penyebaran Corona virus Disease (COVID-19). Pada poin ke 2, dibahas mengenai proses belajar dari rumah yang dilaksanakan dengan ketentuan sebagai berikut:

a. Belajar dari rumah melalui pembelajaran daring/ jarak jauh dilaksanakan untuk memberikan pengalaman belajar yang bermakna bagi siswa, tanpa terbebani tuntutan menuntaskan seluruh capaian kurikulum untuk kenaikan kelas maupun kelulusan;

b. Belajar dari rumah dapat difokuskan pada pendidikan kecakapan hidup antara lain mengenai pandemi COVID19 ;

c. Aktivitas dan tugas pembelajaran belajar dari rumah dapat bervariasi antarsiswa, sesuai minat dan kondisi masing-masing, termasuk mempertimbangkan kesenjangan akses/ fasilitas belajar dirumah;

d. Bukti atau produk aktivitas belajar dari rumah diberi umpan balik yang bersifat kualitatif dan berguna dari guru, tanpa diharuskan memberi skor/nilai kuantitatif.

Akan tetapi, kebijakan tersebut tidak serta merta membuat pembelajaran daring menjadi efektif bagi semua kalangan. Hambatan dalam pembelajaran daring ialah kurangnya fasilitas terpadu teknologi, keterbatasan aksesibilitas internet, dan keterbatasan biaya (C et al., 2020).

Adapun tujuan dari penelitian ini adalah untuk mengidentifikasi permasalahan, kesulitan, dan dampak 
yang dirasakan oleh orang tua dan guru siswa TK dan SD serta cara orang tua dan guru untuk menyesuaikan sistem pembalajaran di rumah dalam menghadapi situasi pandemi COVID-19 yang mengharuskan anak melakukan pembelajaran di rumah atau learning from home (LFH). Selain itu, penelitian ini juga bertujuan untuk melihat pendapat dari orang tua siswa TK dan SD serta guru terhadap pembelajaran daring bagi siswa TK dan SD kelas rendah. Penelitian ini bermanfaat untuk menjadi pertimbangan untuk tenaga pendidik siswa TK dan SD dalam menerapkan sistem LFH yang seimbang dan tidak menyulitkan orang tua.

\section{TINJAUAN PUSTAKA}

\section{Learning From Home}

Learning from home atau yang biasa disingkat LFH adalah suatu kebijakan yang diambil Pemerintah Indonesia dengan menerapkan sistem pembelajaran daring untuk seluruh aktivitas pendidikan di lembaga pendidikan (Astini, 2020). Sejak adanya pandemi COVID-19 ini, seluruh aktivitas masyarakat dibatasi, begitu juga dengan aktivitas pendidikan. Pembelajaran daring didefinisikan sebagai suatu sistem pembelajaran yang dilakukan dengan tidak tatap muka dan menggunakan media yang bisa membantu untuk memperlancar proses belajar (Handarini \& W, 2020).

$$
\text { Menteri Pendidikan dan }
$$

Kebudayaan, Nadiem Anwar Makarim menerbitkan Surat Edaran Nomor 4 Tahun 2020 pada Satuan Pendidikan dan Nomor 36962/MPK.A/HK/2020 tentang Pelaksanaan Pendidikan dalam Masa darurat corona virus disease (COVID-19) maka kegaiatan belajar dilakukan secara daring (online) dalam rangka pencegahan penyebaran corona virus disease (COVID-19) (Menteri Pendidikan, 2020).

\section{Efektivitas}

Efektivitas adalah satuan untuk menyatakan ketercapaian target (Choiroh, 2020). Dalam Kamus Besar Bahasa Indonesia (2019), efektif memiliki arti sebagai memberi akibat, berpengaruh, dan keberhasilan. Salah satu indikator pengukur keefektifan pembelajaran adalah tercapainya tujuan pembelajaran. Tujuan pembelajaran dapat didefinisikan dengan tercapainya hasil yang maksimal bagi siswa dan siswa mengerti pembelajaran yang disampaikan oleh guru. Dalam prinsip ekonomi makro, efektivitas juga dapat diartikan dengan tercapainya suatu tujuan dengan maksimal dan memanfaatkan hal di sekeliling yang ada (Mankiw, 2006).

\section{Metode Penyampaian Materi}

Menurut Astini (2020) selama masa pandemi COVID-19 ini, metode penyampaian materi adalah dengan metode e-learning. E-learning adalah suatu teknologi informasi dan komunikasi untuk memungkinkan siswa dalam mengakses materi di mana pun dan kapan pun. Terdapat 2 tipe e-learning yaitu: Synchronoustraining yang berarti proses pembelajaran terjadi secara bersamaan antara tenaga pendidik dan peserta didik. Proses pembelajaran pada tipe ini terjadi jika tenaga pendidik dan peserta didik secara bersamaan mengakses internet. Hal ini bisa terjadi jika tenaga pendidik dan peserta didik tidak berada di tempat yang sama dan tenaga pendidik memberi materi kepada peserta didik untuk dipelajari secara individual. Kelas virtual adalah salah satu contoh tipe synchronoustraining.

Tipe kedua yaitu tipe Asynchronoustraining dimana peserta didik dapat mengakses materi kapan pun dan menyelesaikannya sesuai dengan rentang waktu yang tertera. WhatsApp merupakan salah satu contoh media komunikasi yang sering digunakan khalayak umum dan juga salah satu 
contoh asynchronoustraining. Selain WhatsApp, video pembelajaran juga merupakan contoh tipe kedua. Ada banyak sekali platform digital yang bisa digunakan sebagai sarana untuk mendukung pembelajaran daring, yaitu (1) zoom meeting, (2) Google meet, (3) WhatsApp chat atau WhatsApp group, (4) Edmodo, (5) Google classroom, dan sebagainya (Handarini \& W, 2020).

\section{Manajemen Waktu}

Manajemen waktu adalah perencanaan, penggerakkan, pengorganisasian, dan pengawasan pada produktivitas waktu (Nurhidayanti, 2016). Selain itu, manajemen waktu juga bisa diartikan sebagai proses keseharian yang digunakan untuk membagi waktu, menyusun jadwal, dan membuat daftardaftar hal apa saja yang akan dilakukan (S. Purwanto, 2008). Manajemen waktu dibagi menjadi 3 aspek yaitu (1) penetapan tujuan dan prioritas, (2) mekanisme manajemen waktu, (3) kontrol terhadap waktu (Tiger, 1999). Berdasarkan hal tersebut, dapat disimpulkan bahwa seseorang harus menentukan skala prioritas dan daftar hal yang ingin dikerjakan agar manajemen waktunya dapat berjalan dengan baik.

\section{METODOLOGI PENELITIAN}

Penelitian ini merupakan penelitian kualitatif dengan pengumpulan data melalui wawancara online dengan WhatsApp call dan direkam oleh aplikasi voice note pada laptop. Strategi metodologi yang digunakan ialah dengan studi kasus karena pembahasan dan topik yang diangkat adalah masalah khusus dan yang sedang menarik untuk dikaji. Metode wawancara secara pribadi dipilih penulis agar penulis bisa menggali informasi dengan detail dari tiap informan yang berbeda latar belakang dan peran. Lamanya wawancara ini berlangsung selama 15 menit sampai dengan 30 menit yang mana setiap informan melakukan satu kali sesi wawancara. Proses wawancara ke-empay informan dilakukan pada hari, tanggal dan jam yang berbeda, berkisar pada bulan April hingga Juli 2020. Dalam penelitian ini terdapat 4 informan yaitu 1 orang tua siswa TK (informan 1), 1 orang tua siswa SD (informan 2), 1 guru SD (informan guru), dan 1 informan pendamping orang tua siswa SD. Informan yang penulis pilih ialah orang tua yang sehari-harinya bekerja kantor, yang mana para informan juga mengalami WFH selama masa pandemi ini. Data yang sudah diperoleh selanjutnya ditranskripsi, diolah dan disajikan dalam bentuk narasi untuk memperoleh gambaran umum secara keseluruhan mengenai dampak dari adanya LFH bagi siswa TK dan SD kelas rendah serta bagi guru.

Pelaksanaan penelitian terdiri dari beberapa tahap yaitu menentukan topik penelitian, penyusunan pertanyaan yang berfungsi untuk mempermudah proses pengambilan data, pengumpulan data, dan analisis data. Pertanyaan kepada informan dikelompokkan menjadi 3 kategori yaitu, (1) dampak positif dan negative adanya LFH, (2) cara orang tua dan guru menyesuaikan diri dan beradaptasi dengan adanya LFH, dan (3) solusi atau tanggapan dari orang tua dan guru untuk sistem LFH yang baik. Analisis data dilakukan dengan cara menyusun transkrip wawancara dari masing-masing informan yang didalamnya terdapat proses pencodingan dan kategorisasi. Proses coding merupakan penyusunan jawaban terhadap pertanyaan yang diajukan kepada informan. Pada proses ini setiap jawaban kemudian dipadatkan sesuai fakta dan diberikan kode serta interpretasi sesuai dengan pemadatan fakta yang akan mempermudah proses selanjutnya yaitu kategorisasi. Proses kategorisasi merupakan penyusunan pemadatan fakta dan interpretasi dari hasil coding yang lebih detail sehingga dapat merumuskan abstraksi penelitian ini. Hasil dan 
pembahasan dari analisis ini dikaitkan dengan beberapa teori dan disajikan dalam bentuk naratif.

\section{HASIL PENELITIAN DAN PEMBAHASAN}

Sesuai dengan Surat Edaran Menteri Pendidikan dan Kebudayaan Nomor 4 Tahun 2020 tentang Pelaksanaan Kebijakan Pendidikan Dalam Masa Darurat Penyebaran COVID-19 dijabarkan mengenai sistem sekolah selama masa pandemi COVID-19 ini. Kemendikbud juga memberikan kebebasan bagi tiap sekolah untuk memilih platform mana yang akan dipakai untuk pembelajaran daring (LFH). Pada bab ini, akan dipaparkan hasil dari wawancara dengan informan dan pembahasan dari penulis berkaitan dengan kesesuaian teori dan pendapat penulis.

1. Dampak dan Kesulitan Bagi Orang Tua Pembelajaran daring ini memiliki dampak positif bagi orang tua yaitu anak menjadi lebih paham materi yang tentunya berdampak pada nilai test sang anak yang jauh lebih baik, selain itu anak menjadi punya aktivitas selama berada di rumah. Hambatan bagi orang tua dalam memenuhi kewajiban untuk mengajari anak adalah di waktu, karena kedua informan orang tua tersebut juga bekerja kantor. Terlebih informan 2 tidak WFH dan harus ke kantor setiap harinya. Hal tersebut juga menyebabkan orang tua sering kewalahan dengan tugas anak yang selalu baru setiap harinya, dan alhasil mau tidak mau orang tua memaksa anak untuk kerja lembur mengerjakan tugas dan membuat perjanjian untuk mau mengerjakan tugas dengan orang lain agar tidak kewalahan lagi. Cara atau strategi yang orang tua pakai untuk mengajar sang anak adalah dengan memberi reward jika sang anak berhasil menyelesaikan tugas, juga dengan teknik meniru yang mana orang tua memberi contoh terlebih dahulu dan sang anak mengikuti. Selama LFH dan mengajari anak, orang tua (informan
2) dibantu oleh anak sulungnya, sedangkan informan 1 dibantu oleh asisten rumah tangga. Semenjak adanya LFH, produktivitas orang tua tidak terganggu karena orang tua mengatur waktu sedemikian rupa agar seimbang antara mengajari anak dengan bekerja. Jika pada satu kesempatan orang tua terpaksa membawa pekerjaan ke rumah, informan akan mengajari anaknya terlebih dahulu baru mengurusi pekerjaan-nya. Dengan adanya LFH ini, orang tua mau tidak mau harus belajar kembali dan mengingat materi pelajaran anak, selain juga belajar sabar. Akan tetapi, semenjak adanya LFH orang tua harus menyediakan waktu lebih untuk mengajar sang anak dan anak pun tidak konsen dalam belajar karena terganggu situasi yang tidak sekondusif di sekolah. Dampak lain yang cukup dirasakan oleh orang tua adalah dari sisi ekonomi yang mana adanya biaya tambahan untuk membeli kuota belajar atau pemasangan wifi di rumah untuk membantu kegiatan LFH ini. Informan 1 dan 2 menyatakan bahwa semenjak adanya LFH, frekuensi mereka membeli kuota yang biasanya sebulan sekali menjadi sebulan 2 sampai 3 kali dan bahkan informan 2 sampai harus memasang wifi di rumahnya agar sang anak dapat belajar tanpa terjadi gangguan sinyal. Orang tua berharap meskipun LFH, guru tetap membuat semacam kelas virtual agar sang anak bisa bertemu tatap muka dengan guru karena anak lebih patuh kepada guru daripada kepada orang tua.

\section{Dampak dan Kesulitan Bagi Anak}

Tetapi, jika dilihat dari segi anak, anak lebih suka diajar oleh orang tua karena orang tua mengajar lebih sabar. Menurut pemaparan dari informan 2, anaknya merasa kesulitan dalam hal pelajaran matematika karena sang anak memang lemah pada pelajaran tersebut, dan menggambar sehingga orang tua sesekali membantu anak untuk 
mengerjakan

tugasnya.Menurut

pemaparan dari informan 1 , anaknya mengalami kesulitan dalam mengerjakan tugas video karena kerap sekali diganggu oleh kakaknya dan kurang percaya diri, selain itu juga sang anak kesulitan dalam menyelesaikan tugas yang terlalu banyak seperti tugas mewarnai di kertas besar, sehingga orang tua pun turut ambil peran membantu sang anak menyelesaikan tugasnya.

Selain itu, dari sudut pandang pendamping pengajar selain orang tua (anak sulung informan 2), informan menyampaikan bahwa tidak adanya perbedaan signifikan saat sebelum maupun sesudah adanya LFH bagi siswa SD. Informan tersebut juga tidak menemukan kesulitan yang begitu berarti selama mendampingi belajar sang adik karena adiknya adalah anak yang penurut. Informan ini adalah seorang mahasiswa yang berkuliah dari pagi sampai sore, dan baru bisa mendampingi belajar sang adik saat malam hari. Cara informan untuk mengajari sang adik yang lemah dalam mata pelajaran matematika adalah dengan mengajari konsep nya terlebih dahulu baru membiarkan sang adik mengerjakan tugasnya sendiri. Selain itu, semenjak adanya LFH informan tidak kewalahan karna jam kuliah dan jam mengajari sang adik tidak bertabrakan. Informan juga berharap untuk guru bisa lebih kreatif dalam melakukan metode pembelajaran daring agar siswa tidak mudah bosan.

\section{Dampak dan Kesulitan Bagi Guru}

Dengan adanya LFH ini, guru menjadi lebih tertantang untuk belajar teknologi yang berkaitan dengan pembuatan video pembelajaran. Selama LFH, informan guru memakai metode video pembelajaran untuk menyampaikan materi kepada siswa. Selama pembuatan video pembelajaran tersebut, informan tidak menemukan kesulitan yang begitu berarti hanya pada masalah jaringan internet saja dan pengulangan take video.
Selama guru memakai metode ini, tidak pernah ada orang tua yang mengeluh. Nilai tes atau ulangan siswa selama pandemi juga semakin baik meskipun bisa saja itu tidak murni atau dibantu oleh orang tua. Guru mensiasati dengan menggabungkan nilai secara keseluruhan saat kelas tatap muka dan kelas online agar terlihat nilai siswa secara murni, juga karena guru sudah mengetahui karakter anak dan paham kemampuan siswanya. Dampak yang guru rasakan selama LFH ini ialah meskipun informan berada di rumah namun aktivitas tetap padat seperti pada keadaan normal dan informan harus menyediakan waktu lebih untuk membuat dan mengedit video pembelajaran untuk diberikan ke siswa. Informan selalu membuat jadwal agar tidak kewalahan selama pembuatan video dan mengurus keperluan rumah tangga. Informan berpendapat bahwa LFH membawa dampak posiitif bagi guru dimana guru harus mengasah ide kreatif nya untuk membuat pembelajaran semenarik mungkin dan sesuai dengan Surat Edaran dari Menteri Pendidikan bahwa LFH tidak menekankan pada nilai akademis saja, namun juga pada pendidikan karakter.

Sebelum diberlakukannya LFH pihak sekolah memberi pembekalan berupa panduan kepada orang tua siswa mengenai metode pembelajaran selama LFH. Menurut orang tua dan pendamping belajar selain orang tua, pembelajaran daring kurang efektif bagi siswa TK dan SD karena sang anak lebih menuruti guru daripada dengan orang tua nya sendiri. Hal ini selaras juga dengan pendapat dari informan guru selaku guru SD di salah satu sekolah dasar. Beliau menyatakan bahwa pembelajaran daring bagi siswa dengan kelas rendah kurang efektif karena pada masa itu seharusnya siswa bisa melatih komunikasi dan sosialisasi dengan sesamanya. Hasil penelitian dari Choiroh (2020) juga menyatakan bahwa pembelajaran daring bagi siswa dirasa kurang efektif (studi pada 5 responden). 
Dinyatakan bahwa aplikasi pembelajaran daring hanya berpusat pada pemberian tugas harian dan guru hanya memberi materi melalui platform yang dipakai. Selain itu, jika ada pertanyaan maka guru dan peserta didik tidak bisa leluasa bertanya seperti saat kelas tatap muka. Hal yang sama pun disampaikan oleh (Satrianingrum \& Prasetyo, 2020) dalam penelitiannya yang menyatakan bahwa guru kurang leluasa dalam mengontrol kegiata siswa nya dikarenakan keterbatasan akses dan keterbatasan ruang lingkup.

Komunikasi antara orang tua dengan guru cenderung satu arah saja, yaitu ketika guru memberikan tugas baru di pagi hari di WhatsApp group dan orang tua mengirimkan tugas anak di grup tersebut. Menurut (Satrianingrum \& Prasetyo, 2020) penggunaan media WhatsApp group sebagai media penyaluran materi menurunkan minat siswa untuk belajar karena didominasi oleh teks yang membuat bosan sang anak. Penelitian Daheri et al. (2020) menyatakan bahwa penggunaan WhatsApp group sebagai media penyampaian materi selama pembelajaran daring dirasa kurang efektif karena kurangnya penjelasan mendetail dari guru, jaringan internet, dan pekerjaan orang tua yang mengharuskan orang tua bekerja di kantor padahal tugas harian dari sekolah dikirim ke WhatsApp orang tua. Pada penelitian yang dilakukan oleh Anugrahana (2020) pun disebutkan bahwa guru banyak yang memilih media WhatsApp sebagai media pembelajaran karena dirasa lebih mudah untuk dipahami dan bukan suatu yang asing bagi banyak kalangan. Akan tetapi, pada penelitian ini guru lebih memilih memakai media video pembelajaran sebagai media belajar agar siswa lebih mudah memahami materi pembelajaran yang disampaikan. Menurut pemaparan informasi dari informan guru, beliau membuat video pembelajaran dan selanjutnya dikirim ke WhatsApp grup orang tua serta melampirkan tugas yang harus diselesaikan sang anak. Dalam penelitian ini dikatakan bahwa orang tua berharap agar guru dapat lebih kreatif lagi dalam menyampaikan materi agar tidak terkesan monoton. Sedangkan dalam penelitian ini hal yang menjadikan pembelajaran daring tidak efektif bagi siswa TK dan SD serta guru dan orang tua adalah rendahnya konsentrasi anak dan kurangnya sosialisasi anak dengan teman sebaya atau dengan guru.

Berdasarkan penelitian dari A. Purwanto et al. (2020), dampak dari adanya LFH bagi anak adalah mereka akan kehilangan jiwa sosial nya karena mereka tidak bisa bertemu secara langsung dengan teman-teman nya yang mana membuat interaksi sosial mereka berkurang. Hal ini selaras dengan pemaparan informan 2 yang menyatakan bahwa adanya LFH ini membuat interaksi sang anak berkurang karena tidak keluar rumah dan belajar di rumah saja. Selain itu, pada penelitian ini juga memaparkan bahwa dampak yang dirasakan oleh orang tua salah satunya adalah orang tua harus menyediakan waktu ekstra untuk mengajari dan membantu anak dalam mendampingi pembelajaran daring. Hal ini pun juga selaras dengan yang disampaikan oleh informan 1 dan informan 2 yang terkendala oleh waktu karena harus meluangkan waktu untuk mengajari dan membantu anak dalam pembelajaran daring. Pada penelitian A. Purwanto et al. (2020), dibahas mengenai dampak bagi guru yang salah satunya adalah guru harus beradaptasi dengan kemajuan teknologi untuk mendukung pembelajaran online, hal ini pun selaras dengan pemaparan informan guru dalam hasil penelitian.

Berdasarkan hasil wawancara 2 informan yang berperan sebagai orang tua, di sekolah tempat anak nya menimba ilmu memakai tipe Synchronous karena materi diberikan di WhatsApp grup yang berisi orang tua dan guru, selanjutnya 
orang tua juga mengumpulkan tugas anak pada grup tersebut. Hal ini berbeda dengan yang dilakukan oleh informan guru. Metode pembelajaran yang beliau pakai adalah dengan video pembelajaran atau dengan tipe Asynchronous. Dalam hal manajemen waktu, baik informan 1, informan 2, maupun informan guru menerapkan manajemen waktu dengan memperhatikan 3 aspek seperti yang terlampir pada tinjauan pustaka. Hal ini terbukti dengan implementasi setiap aspek yang jika dijabarkan sebagai berikut,

a. Menetapkan Tujuan dan Prioritas

Informan 1 dan informan 2 memilih menyelesaikan pekerjaan kantor di kantor dan tidak membawa pekerjaan ke rumah, agar tidak mengganggu saat mengajar anak. Selain itu, informan 1 juga membuat perjanjian dengan sang anak untuk mengerjakan sebagian tugas dengan asisten rumah tangga dan sebagian lagi dengan informan. Hal ini dilakukan agar tidak kewalahan. Informan guru memilih membuat video dari jauh hari dan sebelumnya sudah membuat jadwal take video terlebih dahulu.

b. Mekanisme Waktu

Para orang tua membagi mekanisme waktu mereka dalam sehari dengan pagi sampai sore bekerja dan sepulang bekerja mengajari anak dan membantu mengerjakan tugas sang anak. Kemudian, guru membagi waktunya dengan bekerja mulai pagi hari sampai siang untuk pembelajaran daring dan sore hari sampai malam membuat video pembelajaran dan sebelumnya melanjutkan pekerjaan rumah.

c. Kontrol Waktu

Informan 2 melakukan kontrol waktu dengan menyesuaikan mood anak dan mengajar mulai sore hari, dan terkadang dibantu oleh anak sulung nya. Informan 1 melakukan kontrol waktu dengan membagi waktu anak untuk mengerjakan tugas 2 waktu, yaitu pagi sampai siang dengan asisten rumah tangga dan dilanjutkan sore sampai malam dengan informan 1 . Informan guru melakukan kontrol waktu dengan bekerja mulai pagi hari sampai malam hari seperti dalam keadaan normal.

Apabila manajemen waktu dilakukan dengan maksimal, maka seharusnya informan 1 dan informan 2 tidak mengalami kewalahan selama masa pandemi. Berdasarkan hasil wawancara, informan 1 mengalami kendala waktu karena mempunyai 2 anak yang keduanya juga LFH selama masa pandemi ini. Informan 2 mengalami kendala dari anaknya yang suasana hatinya sangat berubah-ubah (moody), sehingga informan 2 tidak mau memaksa anak jika sang anak sedang tidak berminat untuk belajar. Guru tidak mengalami kendala dalam waktu, tetapi kendala dalam hal teknis. Kendala teknik yang sering guru alami berkaitan dengan jaringan internet dan kuota yang cepat sekali habis. Hal ini selaras dengan penilitian dari Anugrahana (2020) yang menyebutkan bahwa hambatan dalam pembelajaran daring salah satunya adalah fasilitas internet yang dimiliki individu.

Perlu adanya sosialisasi atau bimbingan dari sekolah pada guru dan orang tua mengenai penggunaan media pembelajaran daring sangatlah penting, karena hal ini dapat berdampak pada gap pembelajaran yang diterima oleh anak (Wiresti, 2020). Selain itu, perlunya peran Pemerintah dan instansi terkait untuk memberikan bimbingan teknologi bagi orang tua dan guru seperti sosialisasi mengenai cara menggunakan platform untuk pembelajaran daring dan sebagainya melalui media sosial atau pun media cetak. Adapun respon dan solusi yang orang tua serta guru berikan untuk pembelajaran daring adalah adanya evaluasi dan perbaikan metode pembelajaran yang tepat yang bisa guru gunakan untuk mengajar dan perlunya komunikasi yang lebih intens lagi antara 
guru dengan orang tua. Hal yang sama pun disampaikan pada penelitian Jamilah (2020) yang menyatakan bahwa guru harus mengevaluasi kembali dan menentukan metode pembelajaran yang paling baik yang bisa diimplementasikan pada pembelajaran daring di masa pandemi ini.

Berdasarkan hasil wawancara dengan informan dan beberapa penelitian terdahulu, penulis mendapatkan tiga faktor yang mempengaruhi keberhasilan LFH yaitu,

1. Teknologi yang memadai

Dalam pembelajaran daring, tentunya teknologi adalah hal yang paling utama karena tanpa adamya akses internet atau teknologi yang memadai tentu pembelajaran daring tidak bisa terlaksana dengan baik (Astini, 2020). Selain itu, orang tua juga harus bisa mempersiapkan teknologi yang memadai sehingga anak bisa mengikuti pembelajaran online dengan baik (A. Purwanto et al., 2020). Teknologi juga harus dikuasai oleh guru, karena guru sebagai pengajar harus bisa membuat pembelajaran daring yang menarik bagi anak agar materi tersampaikan dengan baik. Maka dari itu, guru perlu mendapat pelatihan atau pengajaran yang memadai (Wiresti, 2020).

2. Metode pembelajaran daring

Menurut Syarifudin (2020), meskipun pembelajaran dilaksanakan daring, harus tetap dipersiapkan dengan baik dan memilih metode yang sesuai agar tujuan dan capaian materi tetap dapat terlaksana. Setelah memasuki era revolusi 4.0, pendidikan yang tadinya berfokus pada teknik pembelajaran secara tradisional, sekarang haruslah memanfaatkan teknologi sebagai media pembelajaran (Utomo, 2019.), terlebih selama masa pandemi ini yang mengharuskan melakukan pembelajaran jarak jauh, pemilihan metode pembelajaran yang tepat sangat diperlukan agar materi tetap dapat tersalurkan pada siswa dengan baik. Metode pembelajaran yang dipakai selama pembelajaran daring juga berpengaruh pada tingkat keberhasilan proses belajar tersebut. Metode pembelajaran yang bisa dipakai selayaknya sudah memanfaatkan kemajuan teknologi agar siswa tidak bosan selama pembelajaran sedang berlangsung (Choiroh, 2020). Perlu diingat bahwa metode pembelajaran yang biasa dipakai saat tatap muka belum tentu dapat diimplementasikan pada pembelajaran daring.

3. Peranan orang tua

Dalam proses pembelajaran daring sangat diperlukan peranan orang tua sebagai perantara antara guru dengan siswa (anak). Pembelajaran daring mengharuskan orang tua juga untuk ikut serta aktif membantu anak nya selama pembelajaran daring dan orang tua harus serta merta terlibat langsung dalam membimbing sang anak. Selain itu, orang tua juga harus melek teknologi (Astini, 2020) dan menyiapkan sarana pra sarana yang dibutuhkan selama pembelajaran daring berlangsung seperti gadget. Pembelajaran daring akan terlaksana dengan baik jika orang tua berperan secara maksimal untuk mendukung proses pembelajaran tersebut. Menurut Azizah \& Mastoah (2020), salah satu peran orang tua selama pembelajaran daring ialah memastikan anak dalam keadaan baik dan senang selama melakukan pembelajaran dengan melakukan strategi pembelajaran yang sesuai. Hal ini dinilai cukup penting karena strategi yang dipakai oleh orang tua akan menentukan juga keberhasilan pembelajaran daring bagi anak.

Adapun keterbatasan dalam penelitian ini ialah kurangnya jumlah 
sample yang digunakan karena banyak orang tua dan guru yang tidak bersedia di wawancara, juga tidak adanya wawancara secara mendetail dengan siswa TK dan SD karena sang anak malu dan takut untuk menjawab pertanyaan, sehingga orang tua mewakili jawaban sang anak. Selain itu juga keterbatasan dalam hal informasi dari orang tua dan siswa yang masih takut untuk memberi penjelasan kepada penulis. Hambatan lain yaitu karena penelitian dilakukan secara daring maka penulis kurang bisa menggali informasi lebih dalam dari informan.

\section{KESIMPULAN}

Berdasarkan penelitian dan pembahasan diatas, maka dapat disimpulkan bahwa kendala dan permasalahan yang dirasakan oleh orang tua dan guru selama masa pandemi dan LFH ini adalah di manajemen waktu dan masalah teknis saja seperti jaringan internet. Selain itu kesulitan yang orang tua hadapi ialah pada suasana hati anak yang mudah berubah dan keterbatasan waktu serta kendala dalam hal teknis dan waktu untuk pembuatan video (guru). Adapun dampak yang dirasakan oleh orang tua dan guru adalah sama-sama harus meluangkan waktu lebih untuk mengajar anak dan membuat video pembelajaran dan adanya pengeluaran tambahan untuk membeli kuota atau pemasangan wifi demi mendukung pembelajaran anak. Adapun cara orang tua untuk beradaptasi dengan situasi ini adalah membagi waktu dengan baik dan memanfaatkan teknologi yang ada. Selain itu, orang tua dan guru merasa pembelajaran daring bagi siswa TK dan SD dirasa tidak efektif karena jiwa sosialisasi anak menjadi berkurang dan anak menjadi tidak konsen belajar selama di rumah.

Selain itu, ada tiga faktor yang mempengaruhi keberhasilan LFH yaitu, (1) teknologi yang memadai, (2) metode pembelajaran daring, dan (3) peranan orang tua. Harapan dari orang tua adalah guru bisa memberikan virtual kelas pada sang anak dan harapan dari guru adalah hendaknya LFH ini dimaknai positif oleh guru-guru lain.

Adapun saran untuk penelitian selanjutnya ialah diharapkan bisa mencari informan lebih banyak lagi terkhususnya dapat mewawancarai sang anak agar informasi yang didapat lebih akurat. Selain itu, jika wawancara bisa dilakukan secara langsung lebih baik agar lebih bisa menggali informasi dari informan.

\section{DAFTAR PUSTAKA}

Anugrahana, A. (2020). Hambatan , Solusi dan Harapan: Pembelajaran Daring Selama Masa Pandemi Covid-19 Oleh Guru Sekolah Dasar. Scholaria: Jurnal Pendidikan Dan Kebudayaan, 10(3), 282-289.

Astini, N. K. S. (2020). Pemanfaatan Teknologi Informasi dalam Pembelajaran Tingkat Sekolah Dasar pada Masa Pandemi Covid-19. Jurnal Lembaga Penjaminan Mutu STKIP Agama Hindu Amlapura, 11(2), 13-25.

Azizah, N., \& Mastoah, I. (2020). Peranan Orang Tua dalam Pendidikan Anak Sekolah Dasar di Masa Pandemi COVID-19. Pedagogia: Jurnal Ilmu Pendidikan, 18(1).

Choiroh, N. (2020). Efektivitas Pembelajaran Berbasis daring E-Learning dalam Pandangan Siswa. https://iainsurakarta.ac.id/efektifitaspembelajaran-berbasis-daring-elearning-dalam-pandangan-siswa/

Daheri, M., Juliana, J., Deriwanto, D., \& Amda, A. D. (2020). Efektivitas WhatsApp sebagai Media Belajar Daring. Jurnal Basicedu, 4(4), 775783. https://doi.org/10.31004/basicedu.v4i4 .445

Handarini, O. I., \& W, S. S. (2020). Pembelajaran Daring Sebagai Upaya Study From Home (SFH) Selama Pandemi Covid-19. Jurnal Pendidikan Akuntansi Perkantoran, 8(3), 495-503. Jamilah. (2020). Guru Profesional di Era New Normal: Review Peluang dan Tantangan dalam Pembelajaran Daring. 
Premiere Educandum: Jurnal Pendidikan Dasar Dan Pembelajaran, 10(2), 238-247. https://doi.org/10.25273/pe.v10i2.7494

Kamus Besar Bahasa Indonesia. (2019). KBBI Daring. https://kbbi.web.id/efektif

Mankiw, G. N. (2006). Principles od Economics: Pengantar Ekonomi Mikro (3rd ed.). Salemba Empat.

Nurhidayanti, D. D. (2016). Peningkatan Pemahaman Manajemen Waktu Melalui Bimbingan Kelompok dengan Teknik Problem Solving pada Siswa. Psikopedagogia, 5(1), 24-32.

Purwanto, A., Pramono, R., Asbari, M., Santoso, P. B., Wijayanti, L. M., Hyun, C. C., \& Putri, R. S. (2020). Studi Eksploratif Dampak Pandemi COVID19 Terhadap Proses Pembelajaran Online di Sekolah Dasar. Journal of Education, Pshycology, and Counseling, 2(1), 1-12.

Purwanto, S. (2008). Pocket Mentor Manajemen Waktu. Erlangga.

Satrianingrum, A. P., \& Prasetyo, I. (2020). Persepsi Guru Dampak Pandemi Covid-19 terhadap Pelaksanaan Pembelajaran Daring di PAUD. Jurnal Obsesi : Jurnal Pendidikan Anak Usia Dini, 5(1), 633-640. https://doi.org/10.31004/obsesi.v5i1.5 74

Syarifudin, A. S. (2020). Impelementasi Pembelajaran Daring Untuk Meningkatkan Mutu Pendidikan Sebagai Dampak Diterapkannya Social Distancing. Jurnal Pendidikan Bahasa Dan Sastra Indonesia Metalingua, 5(1), 31-34. https://doi.org/10.21107/metalingua.v5 i1.7072

Tiger, T. H. (1999). Time Management: Test of Process Model. Journal of Applied Psychology, 79(3), 381-391.

Utomo, S. S. (n.d.). Guru di Era Revolusi Industri 4.0.

Wahyono, P., Husamah, H., \& Budi, A. S. (2020). Guru Profesional di Masa Pandemi COVID-19: Review Implementasi, Tantangan, dan Solusi Pembelajaran Daring. Jurnal Pendidikan Profesi Guru, 1(1), 51-65. http://ejournal.umm.ac.id/index.php/jp $\mathrm{pg} /$ article/view/12462

Wiresti, R. D. (2020). Analisis Dampak Work From Home pada Anak Usia Dini di Masa Pandemi Covid-19. Jurnal Obsesi : Jurnal Pendidikan Anak Usia Dini, 5(1), 641-653. https://doi.org/10.31004/obsesi.v5i1.5 63 